\title{
EFEKTIVITAS EDUKASI BAHASA ARAB DALAM MENINGKATKAN LITERASI BAHASA ARAB SISWA MADRASAH IBTIDAIYAH
}

\author{
${ }^{1}$ Much. Rachmat Rifa'i, ${ }^{2}$ Lulu Nafisah, ${ }^{3}$ Nur Zakiyah, ${ }^{4}$ Abdul Khobir, ${ }^{5}$ Umi Mahmudah \\ 1,2,3,4,5 IAIN Pekalongan \\ rifailoveeni76@gmail.com
}

\begin{abstract}
ABSTRAK
Penelitian ini bertujuan untuk menganalisis efektivitas kegiatan edukasi bahasa Arab dalam meningkatkan kemampuan anak-anak tingkat Madrasah Ibtidaiyah dalam membaca buku bacaan yang berbahasa Arab melalui. Pada penelitian ini, peneliti menggunakan metode campuran, yaitu menggabungkan metode kuantitatif dan kualitatif. Data kuantitatif diperoleh menggunakan instrumen tes. Sedangkan, data kualitatif diperoleh wawancara yang dilakukan langsung dengan anak-anak. Sampel penelitian adalah sebanyak 22 responden yang merupakan anak-anak tingkat MI di desa Blarakan Kecamatan Kebulen, Pekalongan. Analisis data kuantitatif menggunakan metode paired sample t-test dengan bantuan software SPSS. Hasil penelitian mengindikasikan bahwa kegiatan edukasi bahasa Arab memiliki pengaruh yang signifikan terhadap meningkatnya kemampuan berbahasa Arab. Dengan kata lain, kegiatan edukasi bahasa Arab lebih efektif dalam membantu anak-anak untuk meningkatkan kemampuan membaca buku bertuliskan Arab. Selain itu, hasil analisis juga mengindikasikan bahwa sebelum dilakukannya kegiatan edukasi bahasa arab, kemampuan membaca anak-anak tergolong sedang.
\end{abstract}

Kata Kunci: Edukasi Bahasa Arab, Literasi Bahasa Arab

\section{PENDAHULUAN}

"Bahasa Arab" termasuk salah satu bagian dari mata pelajaran yang ada di beberapa jenjang Pendidikan (Hidayah, 2015). Salah satunya di tingkat Madrasah Ibtidaiyah (MI) atau setara dengan SD. Mayoritas orang mengatakan bahwa mata pelajaran bahasa Arab sangat sulit, sehingga minat siswa menjadi sangat kurang (Himam \& Raswan, 2017). Dua faktor utama yang menyebabkan para siswa kurang termotivasi dalam pembelajaran bahasa Arab meliputi faktor 
eksternal dan internal. Faktor eksternal yang spesifik berasal dari: (1) kompleksitas bahasa Arab; (2) materi dan metode pembelajaran; (3) fasilitas dan lingkungan belajar; dan (4) perilaku dan kepribadian guru. Sedangkan sumber faktor internal adalah: (1) keterampilan dasar dan pengalaman belajar sebelumnya; (2) sikap negatif terhadap mata pelajaran bahasa Arab. Faktorfaktor tersebut perlu diperhatikan oleh guru dan pemangku kepentingan lainnya sebagai acuan dasar untuk meningkatkan motivasi siswa dalam belajar bahasa Arab (Islam, 2015). Sementara itu, Fuadi menyatakan bahwa beberapa faktor yang menyebabkan adanya kesulitan-kesulitan yang dihadapi oleh siswa dalam belajar Bahasa Arab antara lain adalah (1) kurangnya minat dan motivasi siswa untuk belajar bahasa Arab, (2) kesulitan siswa dalam membaca dan memahami makna setiap kosakata bahasa Arab, (3) perhatian orang tua terhadap hasil belajar bahasa Arab siswa kurang, (4) metode penyampaian materi masih monoton, guru hanya menggunakan metode ceramah, akhirnya penggunaan media pembelajaran kurang bervariasi (Fuadi, 2019).

Namun, seiring dengan perkembangan zaman, kini telah banyak ditemukan tempat-tempat bimbingan belajar yang mengajarkan bahasa Arab kepada anak didiknya (Mardliyyah \& Musthofa, 2020). Kegiatan ini dilakukan untuk membantu mereka yang mengalami kesulitan dalam mempelajari bahasa Arab. Selain itu, memberikan informasi lebih banyak kepada mereka mengenai bahasa Arab (Purnama, 2016). Salah satu faktor yang menyebabkan bahasa Arab itu dianggap sulit adalah perbedaan bahasa itu sendiri (Fathuddin, 2015). Mempelajari bahasa Arab tidaklah semudah mempelajari bahasa Indonesia meskipun sama- sama dalam kategori bahasa karena dalam bahasa Arab perlu adanya kemampuan-kemampuan tersendiri yang bersifat khusus agar bisa paham mengenai pelajaran bahasa Arab (Prihantoro, 2019). Salah satunya adalah kemampuan membaca tulisan yang berbahasa Arab (Fitriyah et al., 2019). Apalagi, bagi anakanak tingkat Madrasah Ibtidaiyah (MI) yang baru saja mengenal tulisan-tulisan Arab. Mereka perlu diajarkan hal-hal yang menjadi dasar dari pelajaran bahasa Arab itu sendiri. Di usia mereka yang masih kecil sangatlah mudah untuk mencerna hal-hal yang baru. Karena itu, sangat mudah juga bagi guru untuk memberikan pelajaran di usia mereka. Ada istilah mengatakan, menguasai bahasa asing sama artinya menguasai dunia, maknanya bahwa mempelajari bahasa asing sangatlah penting (Nurislaminingsih \& Perdana, 2019). Salah satunya bahasa Arab, karena bahasa ini juga sudah diakui oleh PBB yang telah menetapkan bahasa Arab sebagai bahasa Internasional (Fayruza \& Yodhi, 2018). Untuk itu, sangat penting untuk mempelajari bahasa Arab sejak dini. 
Kata Edukasi memiliki makna yang sama dengan kata pembelajaran (Mutmainah, 2018). Pembelajaran adalah pendidikan atau usaha sadar, dengan tujuan yang telah ditentukan sebelum proses pelaksanaan, dan pelaksanaannya terkendali. Definisi pembelajaran bahasa Arab yaitu suatu proses kegiatan yang diarahkan dan didorong melalui proses bimbingan dan pengembangan kemampuan bahasa Arab, baik bahasa Arab aktif maupun pasif yang bertujuan untuk memahami ajaran Islam agar sesuai sumber aslinya, yaitu al-Qur'an, Hadist, dan kitab berbahasa Arab (Fayruza \& Yodhi, 2018). Dalam mempelajari bahasa Arab diperlukan juga adanya model pembelajaran (Nasution \& Zulheddi, 2018). Jika dikaitkan dengan bahasa Arab, maka model pembelajaran bahasa Arab adalah mengukur ketercapaian tujuan pembelajaran bahasa Arab melalui kegiatan penilaian berupa keterampilan berpikir, keterampilan pribadi dan sosial, berdasarkan langkah pembelajaran yang sistematis dan terinci baik untuk guru maupun siswa. Dan sebagai pengembang pembelajaran bahasa Arab agar merancang serta merencanakan belajar bahasa Arab lebih menarik (Himam \& Raswan, 2017).

Secara tradisional, literasi dipandang sebagai kemampuan membaca dan menulis (Fitriyah et al., 2019). Kata literasi berasal dari bahasa Inggris literacy dan bahasa latin litera (huruf), yang artinya mengandung pengertian penguasaan sistem penelitian dan kaidah-kaidah yang menyertainya (Nurislaminingsih \& Perdana, 2019). Namun, kata literasi umumnya berkaitan dengan bahasa, dan bagaimana bahasa itu digunakan (Mansyur, 2020). Budaya literasi adalah tentang kebiasaan berpikir, kemudian membaca, menulis, sampai dapat menciptakan karya seni (Saadati \& Sadli, 2019). Serta dapat mewujudkan pendidikan panjang umur dengan budaya membaca (Nurislaminingsih \& Perdana, 2019)). Adanya kegiatan membaca, seseorang dapat mengembangkan dirinya secara terus menerus sepanjang hidupnya (Pujiono, 2017). Kegiatan literasi banyak diminati oleh berbagai kalangan karena kegiatan ini selain mampu menambah pengetahuan juga menyenangkan. Kegiatan membaca merupakan langkah awal bagi seseorang untuk menuju ke keterampilan berbahasa yang lain (Warsihna \& Warsihna, 2016). Karena itu, tujuan peneliti memberikan edukasi pembelajaran bahasa Arab kepada anak-anak adalah untuk membantu mereka agar mampu membaca buku-buku berbahasa Arab dengan baik dan benar. Dengan kata lain, penelitian ini menitikberatkan pada kemampuan membaca materi-materi bahasa Arab pada anak-anak tingkat Madrasah Ibtidaiyah. Alnashr menyatakan bahwa skill membaca dalam bahasa Arab seringkali disebut dengan maharah qira'ah, yang berarti bahwa kemampuan untuk memahami isi kandungan tulisan atau materi bahasa arab dengan baik dan 
benar. Maka, diperlukan langkah-langkah yang sistematis dalam rangka memiliki kemampuan membaca bahasa Arab tersebut (Alnashr, 2019). Kegiatan literasi ini sangat penting karena budaya membaca dan menulis akan berkembang bersamanya (Wulanjani \& Anggraeni, 2019). Selain itu, diharapkan juga kegiatan edukasi bahasa Arab ini dapat memotivasi siswa tingkat MI yang belum bisa membaca untuk membaca, dan memotivasi siswa yang memiliki kemampuan membaca untuk lebih aktif membaca, sehingga bisa meningkatkan minat baca mereka. Adapun kegiatan edukasi Bahasa Arab ini dilakukan di luar jam sekolah dan merupakan program pendampingan belajar pada anak-anak dalam rangka meningkatkan kemampuan bahasa Arab siswa-siswi MI. Apalagi, di tengah Pandemi Covid-19, dimana anak-anak sangat memerlukan dukungan dan pendampingan dari berbagai pihak untuk dapat menjalankan kegiatan belajar online dengan sebaik mungkin.

Kegiatan literasi ini harus dilaksanakan dalam proses pembelajaran, seperti mendengarkan (al-istima'), berbicara (al-kalam), membaca (al-qiroah), dan menulis (al-kitabah) (Nurislaminingsih \& Perdana, 2019). Maka dari itu, peneliti terlebih dahulu memberikan pengetahuan mengenai bahasa Arab kepada anak-anak melalui kegiatan literasi yang dapat memudahkan anak-anak untuk bisa memahami segala hal terkait dengan bahasa Arab secara baik dan sesuai apa yang diharapkan.

\section{METODOLOGI PENELITIAN}

Artikel ini menggunakan metode penelitian campuran (mixed-methods) yaitu sebuah metode yang menggabungkan kuantitatif dan kualitatif (Creswell \& Creswell, 2018). Data kuantitatif diperoleh dengan cara menyebar lembar soal-soal kepada anak-anak sebelum dan sesudah kegiatan edukasi bahasa Arab dilaksanakan. Adapun data kualitatif diperoleh dengan melakukan wawancara mengenai kegiatan edukasi bahasa Arab tersebut.

Program edukasi bahasa Arab yang dilakukan ini di luar jam belajar resmi sekolah dan merupakan program pendampingan belajar bahasa Arab pada anak-anak atas dasar program pemberdayaan masyarakat di tengah Pandemi Covid-19. Kegiatan edukasi atau pembelajaran bahasa arab ini dilakukan dua kali dalam seminggu yaitu setiap hari (Sabtu dan Selasa) pada pukul 10.00 - 11.15 WIB. Pada pertemuan pertama edukasi, peneliti mengenalkan kepada anakanak mengenai kegiatan yang akan dilakukan selama beberapa minggu kedepan. Setelah itu, peneliti juga menyebarkan lembar tes yang berisi pertanyaan-pertanyaan dalam bahasa Arab kepada mereka untuk mengukur pengetahuan dan pemahaman mereka tentang materi-materi 
yang disajikan dalam bahasa Arab. Literasi bahasa arab, yang dalam hal ini mengarah pada kemampuan untuk membaca dan memahami kandungan makna materi bahasa Arab adalah mengikuti indikator-indikator kemampuan membaca bahasa Arab dengan baik dan benar. Ada empat indikator terkait dengan keterampilan berbahasa arab yang digunakan, yaitu mahaaratu al istimaa' (menyimak), mahaaratu al-kalaam (berbicara), mahaaratul al Qiraa'ah (membaca), dan mahaaratu al kitaabah (menulis) (Alnashr, 2019).

Setelah memberikan edukasi bahasa Arab kepada anak-anak, peneliti memberi mereka buku bacaan berbahasa Arab. Setelah mereka menerima pelajaran, mereka diminta untuk membaca buku tersebut selama kurang lebih 20-25 menit. Setelah itu, peneliti menanyakan kepada mereka mengenai materi yang ada di dalam buku bacaan tersebut. Jika ada yang belum mereka pahami peneliti menjelaskan materi itu kepada mereka, sesekali peneliti juga menggunakan alat peraga untuk memberikan materi agar lebih jelas kepada mereka. Dengan bantuan alat peraga tersebut anak-anak dapat lebih mudah memahami bahasa Arab.

Dalam penelitian ini peneliti mengambil responden sebanyak 22 anak-anak. Metode pemilihan sampel yang digunakan adalah purposive sampling, yaitu berdasarkan kebijakankebijakan tertentu dari peneliti (Mahmudah, 2020). Dalam hal ini, peneliti memilih sampel berdasarkan tingkat sekolah, yaitu mereka yang sekolah di Madrasah Ibtidaiyah. Adapun rumusan hipotesis pada analisis data kuantitatif adalah sebagai berikut:

HO: Tidak ada perbedaan rata-rata antara hasil nilai bahasa Arab siswa sebelum dan sesudah diadakannya kegiatan edukasi bahasa Arab.

H1: Ada perbedaan rata-rata antara hasil nilai bahasa Arab siswa sebelum dan sesudah diadakannya kegiatan edukasi bahasa Arab.

Hasil pengujian hipotesis dilakukan menggunakan metode uji $t$ berpasangan (paired sample t-test), dimana data yang digunakan dalam analisis berasal dari kelompok sampel yang sama dengan diberikan sebuah treatment, yaitu edukasi bahasa Arab. Sehingga, menghasilkan kelompok data sebelum dan sesudah dilakukan program edukasi bahasa arab (Mahmudah, 2020). Keseluruhan hasil analisis menggunakan bantuan software SPSS.

\section{HASIL DAN PEMBAHASAN}

Penelitian ini menggunakan sebanyak 22 siswa Madrasah Ibtidaiyah sebagai sampel. Statistik deskriptif yang menunjukkan gambaran umum responden dapat dijabarkan sebagai berikut. Rata-rata dari responden berumur 10 (sepuluh) tahun atau masih duduk di kelas 5 
Madrasah Ibtidaiyah. Kemudian, deskripsi data menunjukkan bahwa kebanyakan dari mereka berjenis kelamin perempuan (67\%) sedangkan responden yang berjenis kelamin laki-laki hanya sebesar 33\%. Dari hasil analisis data menunjukkan bahwa nilai rata-rata sebelum (pre test) diadakannya edukasi bahasa Arab yaitu sebesar 50,54 dengan standar deviasi sebesar 23,07. Sedangkan untuk nilai rata-rata setelah (post test) diadakannya edukasi bahasa Arab sebesar 93,45 dengan standar deviasi sebesar 7,255. Hasil ini bermakna bahwa ada ketidaksamaan hasil belajar siswa dari sebelum dan sesudah diadakannya kegiatan edukasi bahasa Arab. Pada hasil output uji paired sample t-test di atas, diketahui bahwa nilai koefisien korelasi (correlation) sebesar 0,577 dengan nilai signifikansi (Sig.) sebesar 0,05. Jika nilai signifikansi probabilitas 0,05, maka dapat dikatakan adanya korelasi yang positif antara variabel nilai sebelum dan sesudah diadakannya kegiatan edukasi bahasa Arab. Hasil ini juga mengindikasikan bahwa kegiatan edukasi bahasa Arab memiliki korelasi yang positif dan signifikan terhadap kemampuan literasi bahasa Arab siswa.

Lebih lanjut, Table 1 menunjukkan hasil analisis menggunakan uji t berpasangan dengan bantuan software SPSS, yang mana merupakan perbandingan dari data sebelum dan data sesudah dilakukannya program edukasi bahasa Arab kepada peserta didik.

Tabel 1. Paired Sample Test

\begin{tabular}{|c|c|c|c|c|c|c|c|c|}
\hline & \multicolumn{8}{|c|}{ Paired Differences } \\
\hline & \multirow[t]{2}{*}{ Mean } & \multirow{2}{*}{$\begin{array}{l}\text { Std. } \\
\text { Deviati } \\
\text { on }\end{array}$} & \multirow[t]{2}{*}{$\begin{array}{l}\text { Std. } \\
\text { error } \\
\text { Mean }\end{array}$} & \multicolumn{2}{|c|}{$\begin{array}{c}\text { 95\% Confidence } \\
\text { Interval of the } \\
\text { difference }\end{array}$} & \multirow[t]{2}{*}{$t$} & \multirow[t]{2}{*}{$d f$} & \multirow[t]{2}{*}{$\begin{array}{l}\text { Sig. (2- } \\
\text { tailed) }\end{array}$} \\
\hline & & & & Lower & Upper & & & \\
\hline $\begin{array}{l}\text { Sebelum } \\
\text {-Sesudah }\end{array}$ & -4.29 & 19.80 & 422.06 & -51.69 & -34.13 & -10.17 & 21 & 0.00 \\
\hline
\end{tabular}

Dari table 1 mengindikasikan bahwa nilai $t_{\text {hitung }}$ sebesar -10.17 dengan menggunakan derajat kebebasan atau degree of freedom $(d f)$ sama dengan 21. Nilai derajat kebebasan ini dihasilkan dari $n-1=22-1=21$. Adapun pedoman pengambilan keputusan dalam uji paired sample $t$-test adalah jika nilai $p$-value atau signifikansi kurang dari 0,05 maka hipotesis nol (H0) ditolak dan hipotesis alternatif (H1) diterima (Mahmudah, 2020). Selanjutnya, dari tabel 2 juga terlihat bahwa $p$-value atau nilai signifikansi yang dihasilkan adalah sebesar 0,00 , yang mana 
kurang dari $\alpha=0,05$. Hasil pada tabel 1 di atas mengindikasikan bahwa hipotesis nol (H0) yang ditawarkan diputuskan ditolak. Konsekuensinya, pernyataan H0 yaitu "Tidak ada perbedaan ratarata antara hasil nilai bahasa Arab siswa sebelum dan sesudah diadakannya kegiatan edukasi bahasa Arab" adalah tidak bisa diterima yang mana mengarah pada kesimpulan bahwa ada perbedaan rata-rata antara hasil nilai bahasa Arab siswa sebelum dan sesudah diadakannya kegiatan edukasi bahasa Arab. Dengan kata lain, ada pengaruh yang signifikan dari pelaksanaan kegiatan edukasi bahasa Arab terhadap literasi bahasa Arab anak-anak. Kemampuan membaca dengan baik dan benar anak-anak menjadi jauh lebih baik ketika dilakukan edukasi bahasa Arab, yang mana dibuktikan dengan meningkatnya skor post test anak-anak. Hasil analisis pada tabel 1 juga mengindikasikan hasil yang konsisten dengan penelitian sebelumnya, yang mana melaporkan bahwa kegiatan edukasi bahasa Arab, yang merupakan program pendampingan belajar pada anak-anak dapat meningkatkan prestasi siswa. Program pendampingan belajar pada anak-anak mampu meningkatkan prestasi anak-anak. Selain itu, kegiatan belajar di luar jam sekolah juga mampu meningkatkan prestasi siswa (Narindra, 2012).

Jika melihat dari potensi mereka terhadap pelajaran bahasa Arab, sebelum diadakannya kegiatan edukasi bahasa Arab mereka berada pada taraf sedang, artinya kemampuan bahasa Arab mereka standar (tidak terlalu baik dan tidak terlalu buruk). Hal ini bisa memudahkan peneliti untuk memberikan edukasi kepada anak-anak. Selanjutnya, hasil analisis data juga mengindikasikan bahwa kemampuan bahasa Arab peserta masih tergolong sedang, khususnya sebelum diberlakukan kegiatan edukasi bahasa Arab. Setelah kegiatan tersebut, diketahui bahwa kemampuan bahasa Arab mereka mengalami peningkatan yang signifikan, yang mana dapat dilihat pada table $1 \mathrm{di}$ atas. Meskipun mayoritas responden telah mendapatkan materi bahasa Arab di madrasah, mereka masih menghadapi berbagai kesulitan dalam mempelajari materimateri bahasa arab secara keseluruhan. Hasil analisis pada item-item pernyataan wawancara yang diisi oleh peserta didik, baik dari sebelum maupun sesudah diadakannya kegiatan edukasi bahasa Arab, hasilnya mengindikasikan bahwa rata-rata dari mereka menyukai pelajaran bahasa Arab tetapi mereka mengalami kesulitan dalam mempelajarinya. Namun, setelah diadakannya edukasi bahasa Arab, mereka mulai bisa memahami bahasa Arab dengan lebih baik sehingga jarang mengalami kesulitan.

Hasil ini juga relevan dengan jawaban anak-anak pada tahapan wawancara, dimana mayoritas anak menyatakan bahwa belajar bahasa Arab adalah sulit. Namun, setelah dilakukan 
program pendampingan belajar melalui edukasi bahasa Arab, mereka mengubah persepsinya. Mayoritas dari mereka tidak lagi mengatakan bahwa belajar bahasa Arab adalah sulit, namun bisa saja menyenangkan dan cenderung mudah. Hal ini dikarenakan adanya dampingan dan dukungan dari orang dewasa sehingga ketika anak mengalami kesulitan, maka dia bias langsung menanyakan dan meminta penjelasan secara langsung. Selanjutnya, kebanyakan anak-anak juga menyatakan bahwa mereka menjadi suka membaca buku Bahasa Arab karena telah mampu membaca dan memahami materi ataupun cerita dalam bahasa Arab.

Namun demikian, ketika peneliti melakukan kegiatan edukasi bahasa Arab, ada beberapa kendala yang harus dihadapi, diantaranya adalah (1) faktor usia, dimana responden dalam penelitian ini adalah anak-anak yang rata-rata berusia 10 tahun dan masih duduk di bangku kelaas 5 MI. Sehingga, mereka seringkali merasa malas dan bosan untuk mengikuti kegiatan edukasi tersebut. Emosi yang belum stabil dan lebih memprioritaskan bermain daripada belajar menjadi tantangan sendiri dalam menyukseskan kegiatan edukasi bahasa Arab; (2) faktor perbedaan bahasa, mengingat antara budaya negara Indonesia dan negara Arab yang juga berbeda, begitupun dengan bahasa dari kedua negara tersebut; (3) faktor waktu dan ruang gerak, adanya pandemic Covid-19 juga berimplikasi pada sulitnya menemukan waktu dan tempat yang sesuai untuk kegiatan ini, dimana semuanya harus memperhatikan protokol kesehatan yang sangat ketat dalam rangka menghindari terpaparnya virus corona; (4) faktor dukungan orang tua, banyak orang tua yang enggan mendukung anak-anaknya untuk mengikuti kegiatan edukasi bahasa Arab. Walaupun demikian, peneliti tetap melaksanakan tugasnya dengan berusaha semaksimal mungkin. Jadi, dapat peneliti ambil kesimpulan bahwa kemampuan rata-rata anakanak di desa tersebut mengenai pelajaran bahasa Arab masih sedang, namun setelah peneliti mengadakan kegiatan edukasi bahasa Arab terjadi peningkatan kemampuan bahasa Arab.

\section{KESIMPULAN}

Kegiatan edukasi bahasa Arab yang diadakan untuk membantu anak-anak terutama tingkat MI dalam mempelajari bahasa Arab sehingga mereka bisa dengan mudah untuk mampu membaca buku-buku bacaan yang berbahasa Arab. Mempelajari bahasa Arab tidaklah semudah mempelajari bahasa Indonesia meskipun keduanya sama-sama bahasa, karena dalam mempelajari bahasa Arab diperlukan waktu yang tidak sebentar dan juga kesabaran bagi yang ingin bisa bahasa tersebut. Melihat dari kemampuan anak-anak yang jarang sekali bisa membaca tulisan yang berbahasa Arab, maka peneliti mengadakan kegiatan edukasi bahasa Arab. Setelah 
peneliti melakukan penelitian melalui diadakannya kegiatan edukasi bahasa Arab, kemampuan anak-anak dalam mempelajari bahasa Arab terjadi peningkatan. Itu artinya bahwa kegiatan edukasi bahasa Arab sangat efektif untuk meningkatkan kemampuan literasi anak-anak tingkat MI terhadap buku bacaan yang berbahasa Arab. Masyarakat dari desa tersebut juga mendukung kegiatan yang peneliti lakukan.

\section{DAFTAR PUSTAKA}

Alnashr, M. S. (2019). Penilaian Kemampuan Membaca Bahasa Arab Anak Kelas Rendah Madrasah Ibtidaiyah di Kabupaten Pati. ELEMENTARY: Islamic Teacher Journal, 7(1), 149-168.

Creswell, J. W., \& Creswell, D. J. (2018). Research design: Qualitative, quantitative, and mixed methods approaches. United Kingdom, UK. SAGE Publications, Inc.

Fathuddin, U. (2015). Ilmu Allughah Al Ijtimai wa Talim al Lughoh al Arobiyah Li Al Nathiqina Bi Ghairiha. Alsinatuna, 2(1).

Fayruza, A. Z., \& Yodhi, A. B. P. (2018). Literasi Pembelajaran Bahasa Arab Melalui Media Pembelajaran Komik Untuk Siswa Tingkat SD/MI. Seminar Nasional Bahasa Arab Mahasiswa.

Fitriyah, L., Marlina, M., \& Suryani, S. (2019). Pendidikan Literasi pada Pembelajaran Kitab Kuning di Pondok Pesantren Nurul Huda Sukaraja. Titian Ilmu: Jurnal Ilmiah Multi Sciences, 11(1), 20-30.

Fuadi, F. (2019). Analisis Kesulitan Belajar Bahasa Arab. Al-Lisan: Jurnal Bahasa (e-Journal), 4(2), 161-169.

Hidayah, L. L. (2015). Pengembangan Kartu CESAR (Cerdas Aktif Religius) sebagai media pembelajaran keterampilan membaca bahasa Arab dan karakter siswa kelas VIII MTs Al Irsyad Gajah Demak. Universitas Negeri Semarang.

Himam, M. W., \& Raswan, R. (2017). Tamyiz; Model Alternatif Pembelajaran Bahasa Arab Sebagai Bahasa Al-Qur'an. Lisanul Arab: Journal of Arabic Learning and Teaching, 6(1), 18-28.

Islam, A. M. S. (2015). Faktor Demotivasi Pembelajaran Bahasa Arab dalam Perspektif Siswa Madrasah. Arabiyat: Jurnal Pendidikan Bahasa Arab Dan Kebahasaaraban, 2(1), 1-16.

Mahmudah, U. (2020). Metode Statistika: Step by Step. Penerbit NEM.

Mansyur, U. (2020). Minat Baca Mahasiswa: Potret Pengembangan Budaya Literasi di 
Universitas Muslim Indonesia. Literasi: Jurnal Bahasa Dan Sastra Indonesia Serta Pembelajarannya, 4(2), 135-141.

Mardliyyah, A., \& Musthofa, T. (2020). Pengembangan Kurikulum Bahasa Arab di Sekolah Islam Terpadu SMP Luqmanul Hakim Aceh. Al Mahāra: Jurnal Pendidikan Bahasa Arab, 6(1), 59-76.

Mutmainah, F. A. (2018). Pemikiran A. Chaedar Al-Wasilah tentang Pendekatan Literasi (Genre-Based Approach) dan Pembelajaran Bahasa Arab. Jurnal Al Bayan: Jurnal Jurusan Pendidikan Bahasa Arab, 10(1), 121-138.

Narindra, P. (2012). Pengaruh Pemanfaatan Jam Belajar Di Luar Sekolah Dan Pendampingan Belajar Orang Tua Terhadap Hasil Belajar Siswa Kelas V SD Dabin I Kecamatan Andong Kabupaten Boyolali Tahun Ajaran 2011/2012. Universitas Muhammadiyah Surakrta.

Nasution, S., \& Zulheddi, Z. (2018). Pengembangan Model Pembelajaran Bahasa Arab Berbasis Teori Konstruktivisme Di Perguruan Tinggi. Arabi: Journal of Arabic Studies, 3(2), 121144.

Nurislaminingsih, R., \& Perdana, F. (2019). Analisis Aplikasi Teknologi dalam Literasi Bahasa Arab. LIBRARIA: Jurnal Ilmu Perpustakaan Dan Informasi, 57-67.

Prihantoro, S. (2019). Analisis Kesalahan Bahasa Pada Taksonomi Linguistik Dalam Penulisan Insya'. Al Mahāra: Jurnal Pendidikan Bahasa Arab, 5(1), 41-62.

Pujiono, S. (2017). Kopetensi profesional guru Pai di Madrasah aliyah Nurul Sukaraja Kabupaten Oku Timur Provinsi Sumatera Selatan. UIN Raden Intan Lampung.

Purnama, S. (2016). Metode penelitian dan pengembangan (pengenalan untuk mengembangkan produk pembelajaran bahasa Arab). LITERASI (Jurnal Ilmu Pendidikan), 4(1), 19-32.

Saadati, B. A., \& Sadli, M. (2019). Analisis pengembangan budaya literasi dalam meningkatkan minat membaca siswa di sekolah dasar. TERAMPIL: Jurnal Pendidikan Dan Pembelajaran Dasar, 6(2), 151-164.

Warsihna, J., \& Warsihna, J. (2016). Meningkatkan literasi membaca dan menulis dengan teknologi informasi dan komunikasi (TIK). Jurnal Kwangsan, 4(2), 67-80.

Wulanjani, A. N., \& Anggraeni, C. W. (2019). Meningkatkan minat membaca melalui gerakan literasi membaca bagi siswa sekolah dasar. Proceeding of Biology Education, 3(1), 26-31. 